\title{
Training of Doctors of Philosophy in the Kyrgyz Republic in the Context of Modern Trends
}

\author{
Gulmira T. Karabalaeva \\ Kyrgyz National University Named After Jusup Balasagyn \\ Nurbubu A. Asipova \\ Kyrgyz National University Named After Jusup Balasagyn \\ Mayram A. Satybekova \\ Kyrgyz National University Named After Jusup Balasagyn \\ Damira T. Kalibekova \\ Kyrgyz National University Named After Jusup Balasagyn \\ Aisulu S. Bayalieva \\ Kyrgyz National University Named After Jusup Balasagyn
}

The paper deals with the problems of implementing the training of Doctors of Philosophy in higher education institutions of the Kyrgyz Republic (KR) in the context of modern trends. A study was conducted to investigate the readiness of teachers, master's, and bachelor students to implement the PhD programme in pedagogical areas in higher education institutions of the Kyrgyz Republic. The essence of the research of the scientific project is to determine the features of scientific and methodological support for the training of Doctors of Philosophy (PhD) in pedagogical areas and to develop ways to train Doctors of Philosophy in pedagogical areas in the educational process of the university. A questionnaire was developed to study the issues of preparing a PhD programme in pedagogical areas. It is necessary to create a domestic equivalent of the training of PhD in the field of "Pedagogy" while maintaining the existing experience of training scientific and pedagogical personnel, which meets the requirements of synchronisation of educational programmes.

Keywords: modernisation of education, integration, synchronisation, multi-level professional training, PhD programme

\section{INTRODUCTION}

The deepening of market relations in the economy, the expansion of ties with foreign partners, the possibility of traveling abroad for Kyrgyz citizens, the opening of interstate universities, and the associated problems of recognition and acceptance of educational documents - all these become the main factors of 
structural and substantive reforms of higher education. The increasing attention to the issues of postgraduate education, in particular, to $\mathrm{PhD}$ programmes in European countries, is due to the new problems associated with mass external and internal migration in the post-Soviet countries, the need to integrate higher education in the Kyrgyz Republic into the world educational space. For successful social and professional adaptation of Kyrgyz university graduates, it is important to modernise the education system so that it corresponds to global trends and promotes the export of higher education of the Kyrgyz Republic outside its borders. One of the important conditions for compliance with these trends is the implementation of Doctor of Philosophy $(\mathrm{PhD})$ programmes in various scientific fields, which have a centuries-old tradition in foreign universities, but have not yet become a real form of training of scientific and pedagogical personnel in the post-Soviet space, except for Kazakhstan.

The collapse of the Soviet Union contributed to the emergence of socio-cultural changes in the Union republics, which led to radical changes in all areas of education, especially in the higher education system, which today is characterised by democratisation, decentralisation of management, the establishment of market relations, internationalisation of the student population, multi-level and diversified education, a variety of educational programmes and the technologisation of the educational sphere. In the Kyrgyz Republic, this has manifested itself in the continuous universalisation of higher education, which is why the importance of profiling universities is lost. These phenomena are mainly characteristic of all post-Soviet countries that are on the way to modernisation of education according to global trends.

At present time, the structure of the domestic higher education system is a combination of the conventional (Soviet) education system with elements of the British, German, American, as well as other educational systems integrated into the "Bologna" educational model. The characteristics of such hybrid educational systems include updated models of higher education, in which there are structural changes in educational programmes and a variety of innovations, among which one can find remnants of conventional, innovative, and mixed models.

The problems of multi-level personnel training and modernisation of higher professional education at the present stage were the subject of research of teachers of the Kyrgyz Republic. In the works of T.A. Abdyrakhmanov, N.A. Asipova, I.S. Boldzhurova, K.D. Dobaev et al., reveal various aspects of the development of the national system of teacher training. Let us pay special attention to the following studies: the study of theoretical and practical issues of the training of Doctors of Philosophy in the Kyrgyz Republic (Ch.U. Adamkulova, N.A. Asipova, G.T. Karabalaeva), M.Ch. Kozhobekov, K.B. Chekirov, S.K. Mambaeva; discussions on the status and purpose of PhD training (E.R. Sakimbaev, B.K. Tynalieva, etc.). The works of these authors are mainly arranged, they present an analysis of the state of $\mathrm{PhD}$ training in the Kyrgyz Republic.

All this requires the coordination of international policy in the field of education, there should be interdependence and complementarity of national educational systems, "synchronisation of actions achieved based on their regulation by supranational institutions, the gradual outgrowth of national educational systems of their state framework and the emergence of trends towards the establishment of a single educational space as the most effective form of implementing the tasks of the future."

\section{THEORETICAL FRAMEWORK}

Among the studies on the problems of the development of the higher professional education system, a number of works can be distinguished on the problems of globalisation. Thus, A.V. Panibratsev considers the Bologna process as the main way of modernisation and globalisation of higher education, D.A. Meshcheryakov considers the problems of education globalisation and the pan-European educational space, V.M. Danilchenko explores the problems of globalisation and education in the 21 st century.

The globalisation of education is understood as the process of simultaneous expansion of the sphere of educational services of professional education and strengthening the differentiation of professional education according to the following criteria: specialisation, level of education, educational institution, student community. The main problem of the globalisation of education is the representation of national interests in the global world. The process of internationalisation of higher education, involving the 
development and implementation of national educational curricula, can be accompanied only with the existence of national systems of higher education with their distinctive features. These programmes can be exchanged with other countries. They will be attractive for foreign students coming to study in another country, and it will also be possible to arrange staff exchanges, organise joint research and development.

In the scientific and pedagogical literature, the issues of internationalisation are considered in a fairly wide range of phenomena and processes. A.N. Grigoriev and G.V. Korshunov focus on the problem of developing a policy for exporting educational services to the global educational market and teaching foreign students at Russian universities. A.N. Dzhurinsky writes about the revolutionary nature of the process of internationalisation, the growth in higher education of unprecedented scale and diversity of international relations. O.A. Beregovaya and V.I. Kudashov consider the internationalisation of higher education as an objective and purposeful process in a globalising world.

Internationalisation at the level of a higher education institution is the process of turning a national university into an international one, including an international aspect in all components of university management to improve the quality of teaching and research, and achieve the required competencies. Internationalisation helps Kyrgyz universities to exist harmoniously in the global academic educational space, actively develop and improve in it. Nowadays, any university striving for quality and prestige must have at least one foreign university as a partner and implement research or educational programmes together with it.

Authors of this study believe, one of the main signs of the modernisation of higher education is the integration of higher education into a single global space, which should be initiated at the state level. This refers to the entry of Kyrgyzstan into the Bologna process and the transition to a multi-level structure of higher education according to the order of the Government of the Kyrgyz Republic adopted in 2011. The problems of integration of education are considered in the studies of V.M. Koprov, E.V. Sapir and E.A. Pushkareva, where the authors emphasise the importance of studying the integration processes in the field of higher education for their subsequent use in the development of an innovative environment of higher education.

Speaking about the integration of education, it should be remembered that it is carried out at the state level, at which higher educational institutions have additional opportunities for cooperation - united universities (for example, the Kyrgyz-Russian Slavic University (KRSU), the Kyrgyz-Turkish University "Manas" (KTUM), the American University of Central Asia (AUCA), etc., which were established based on inter-state agreements); united dissertation councils (for example, interstate dissertation councils operate in some specialisations together with the Republic of Tajikistan, etc.) all this is implemented by the state.

It is considered that the Bologna process is the main way of modernisation and globalisation of higher education. At the same time, higher professional education should be an instrument of social development, the front line of modernisation. In the multi-level structure of higher professional education, there is a classification of degrees that must be completed at the university. But unlike the Western multi-level structure of higher professional education in many CIS countries, including the Kyrgyz Republic, the transition to bachelor - master degrees does not automatically cancel the specialist degree, since the Bologna process assumes the preservation of national features of universities. For example, in the Kyrgyz Republic, along with obtaining a bachelor's degree (240 credits) and a master's degree (120 credits), a student can obtain a specialist qualification in a number of medical, engineering and creative specialties, studying for 5 years.

All this shows that there have been intra-system changes in the educational system of the Kyrgyz Republic, and the renewal of Kyrgyz higher education today acquires hybrid forms (the creation of stable states or structures, which involves minimising economic costs and improving the quality of the product). According to V.S. Senashenko and A.A. Makarova, the development of national educational systems through the prism of hybridisation is associated with the modernisation of the system of higher professional education, in the studies of scientists of other countries, these problems are also studied, for example, J. N. Pieterse considers globalisation as a hybridisation of higher education and points to the inevitability of this process. 


\section{MATERIALS AND METHODS}

Research tools were developed for the study, i.e. research methods were defined. As the main methods in the study, the authors used such methods as theoretical methods - analysis of scientific and pedagogical literature, study of educational documents, analysis of normative legal documents and acts of universities; empirical methods - observation, conversation, questioning, methods of studying the opinions of teachers, students, master's students regarding the implementation of the $\mathrm{PhD}$ educational programme in pedagogical areas; mathematical methods - processing of survey data.

The essence of the research of the scientific project is: in theoretical terms - the identification of the features of scientific and methodological support for the training of Doctors of Philosophy (PhD) in pedagogical areas, in practical terms - the development of ways to train Doctors of Philosophy in pedagogical areas in the educational process of the university. Consequently, the training of Doctors of Philosophy $(\mathrm{PhD})$ in pedagogical areas is considered as a qualitative breakthrough in the implementation of the educational process in accordance with the principles of international practice of training highly qualified scientific and pedagogical personnel who are competitive in the modern labour market. The project is designed for 3 years and is divided into three stages (2019-2021).

At the first stage, the authors of this study investigated the nature and features of $\mathrm{PhD}$ programmes implemented in foreign universities, analysed the scientific-theoretical foundations and the current state of $\mathrm{PhD}$ training in pedagogical areas in the world educational space and the CIS countries; developed educational and methodological tools for the $\mathrm{PhD}$ programme in pedagogical areas. At the second stage, work was organised to summarise the existing experience of implementing the Doctor of Philosophy (PhD) programme in pedagogical areas and to study the prospects for implementing the Doctor of Philosophy $(\mathrm{PhD})$ programme in pedagogical areas in Kyrgyzstan to ensure integration into the world educational space. The third stage is the preparation of scientific and methodological documents, i.e. the entire set of educational and methodological documentation, starting from the State Educational Standards of Higher Professional Education, curriculum, training programmes, ending with the working programmes of disciplines, as well as the preparation of license documents for the opening of the Doctor of Philosophy $(\mathrm{PhD})$ programme at the Department of Pedagogy of the Higher School of the Kyrgyz National University (KNU) named after J. Balasagyn.

When solving these tasks, it was necessary, first of all, to study the experience of other countries, including the near abroad, since these countries are in a similar educational space and have common historical and cultural traditions and educational orientations. At the same time, these problems should be studied taking into account the specifics, procedure, and results of awarding a $\mathrm{PhD}$ degree in foreign countries. At the second stage of the study, a "Methodology for studying the readiness of teachers, postgraduates, and undergraduates to implement a $\mathrm{PhD}$ programme in pedagogical areas" was developed and a study was conducted. In accordance with the task of the study, the research tools were developed, i.e., the methods and methodology of the study were determined.

In this regard, a questionnaire was developed to study the problems of preparing a $\mathrm{PhD}$ programme in pedagogical areas. 3 types of questionnaires were developed: for teachers, master's, and bachelors. A total of 384 people took part in the experiment. Among them: teachers - 110, postgraduates -92, master's - 182 of the Kyrgyz National University named after J. Balasagyn, Kyrgyz State University (KSU) named after I. Arabaev.

\section{RESULTS AND DISCUSSION}

In accordance with the Law of the Kyrgyz Republic No. 92 "On Education", a multi-level training programme was introduced into the country's system of higher professional education. Since 2012, the Kyrgyz Republic has switched to a two-tier system of higher education, which was focused on the principles of pan-European or global systems, based on which there were changes not only in the structure of higher education, but also in the approaches to education in the Kyrgyz Republic, but with the preservation of national features of universities. By 1998-1999, bachelor's degree programmes were implemented in 22 
higher educational institutions of Kyrgyzstan, and master's degree programmes were implemented in 9 universities. Since the 2012-2013 academic year, 22 higher educational institutions of Kyrgyzstan have started training more actively, and the implementation of master's programmes has begun. The training of highly qualified personnel continued under the postgraduate training programme, which includes postgraduate and doctoral studies and after defending the dissertation allows getting the degree of candidate (doctor) of sciences. At the same time, in 2012, by The Order of the Ministry of Education and Science of the Kyrgyz Republic No. 733/1 of 12.12.12 "On the organisation of an experiment on the development and implementation of doctoral programmes $(\mathrm{PhD})$ ", the working group developed Temporary state requirements for universities implementing pilot doctoral programmes $(\mathrm{PhD})$ of postgraduate professional education. A Temporary Regulation for the implementation of pilot doctoral programmes of postgraduate professional education $(\mathrm{PhD})$ has been developed.

Since 2013, a Western-style doctoral programme has been introduced as a pilot programme, and 6 universities have started implementing $\mathrm{PhD}$ programmes in different areas, thus opening up the possibility of providing educational services that differ not only in content, but also in the final purposes, forms, and terms of their development. With regard to the reform of higher education, as well as the transition of higher education institutions of the Kyrgyz Republic to a multi-level education system, a number of problems arise related to the improvement of postgraduate training of highly qualified personnel. A research project was initiated for the Kyrgyz Republic to develop scientific and methodological ways to move to a new educational and scientific level of training of a young scientist, namely, to find solutions to improve the quality of training of Doctors of Philosophy $(\mathrm{PhD})$ in pedagogical areas. Studying the experience of leading foreign universities is one of the components of the qualitative modernisation of the system of training Doctors of Philosophy (PhD) in Kyrgyzstan. In addition, the holding of events, round tables to discuss the main issues of the Doctor of Philosophy $(\mathrm{PhD})$ training programme made it possible to quickly respond to inconsistencies and adjust the implementation of their training in the activities of the University. The solution of this issue, in authors' opinion, contributes to the scientific project on the topic "Scientific and methodological support for the training of Doctors of Philosophy $(\mathrm{PhD})$ in pedagogical areas", which was approved within the framework of the competition of the Ministry of Education and Science of the Kyrgyz Republic and started its implementation in January 2019.

The first group of respondents was made up of bachelor students of the KNU named after J. Balasagyn and KSU named after I. Arabaev. When defining bachelor students as a focus group, the authors of this study assumed that all of them are mainly studying in pedagogical areas and in the future they will have to continue their pedagogical education in one way or another. From the questionnaires and conversations with students, it was found that students are well aware of the academic degree "master's" and associate it with continuing their studies after the bachelor's degree, and they have heard about the $\mathrm{PhD}$ programme, but they practically do not have the specific knowledge of $\mathrm{PhD}$ training. Of the surveyed students $-40 \%$ answered "yes" (that they would like to get an education in the PhD programme in pedagogical areas), 39\% of students answered "no" (they would not like to continue their studies, as it is necessary to work and improve their financial condition, to define their lifes), and $41 \%$ of students answered "difficult to answer" (they have no clear information about the $\mathrm{PhD}$ training and there is no possibility of continuing their studies in the PhD programme in the direction of "Pedagogy"). An analysis of the responses of bachelor students shows that $40 \%$ intend to enter the $\mathrm{PhD}$ programme in the direction of "Pedagogy" in the future. In this the authors of this study see the optimistic attitude of the majority of students who are at the initial level of professional training, and that many of them vaguely imagine the difficulties associated with scientific activities.

The second group of respondents consisted of master's students of the KNU named after J. Balasagyn and KSU named after I. Arabaev. The survey involved master's students of the Faculty of Kyrgyz Philology, Russian and Slavic Philology, the Faculty of Foreign Languages, the Faculty of Social and Humanitarian Sciences of the KNU named after J. Balasagyn and the Faculty of Chemistry and Biology, as well as the Faculty of History, of the University named after I. Arabaev. When choosing these universities as the object of research, the authors of this study proceeded from the assumption that traditionally these universities mainly train teaching staff for the education system of the Kyrgyz Republic, these universities 
have a master's degree in the field of "Pedagogy", and that the graduates of these universities are mostly focused on professional teaching activities. Based on this, undergraduates were given the following questions during the survey and conversation. To the question "Do you know about the PhD programme abroad and PhD in Kyrgyzstan?" Less than half of the master's students answered that this is a continuation of their studies after the master's degree, and about $80 \%$ of the undergraduates expressed their desire to learn more. $26 \%$ of students spoke about the desire to get an education on the $\mathrm{PhD}$ programme in pedagogical areas, $16 \%$ of master's students answered categorically - no, and 58\% of respondents said that they do not know yet, citing financial difficulties. In contrast to bachelor students, master's students objectively evaluate the training on the $\mathrm{PhD}$ programme, which requires a lot of costs, both mental and material. On the issue of training highly qualified personnel, both bachelor and master's students say that they prefer a full transition to the third level of $\mathrm{PhD}$ training.

The third group consisted of teachers who showed a higher percentage of cognitive knowledge about the PhD programme both in Kyrgyzstan - 52\%, and abroad - 68\%. 28\% of teachers spoke about the desire to get an education on the PhD programme, and 26\% said that they do not know yet. An analysis of the questionnaires and a conversation with teachers showed that more than half of the teachers surveyed (56\%) believe that the conventional system of training candidates and doctors of science is justified and proven practice and that it is too early to open a $\mathrm{PhD}$ programme in different areas since they do not know how this system will be organised. The rest (14\%) believe that it is necessary to implement this system, since sooner or later it is necessary to integrate into the global educational space. $55 \%$ of teachers believe that parallel training of highly qualified personnel through postgraduate (doctoral) and $\mathrm{PhD}$ programmes is correct (14\%). According to the assessment of the capabilities of Kyrgyz Universities for $\mathrm{PhD}$ training at a sufficient level, all respondents spoke: $69 \%$ - students, $66 \%$ - undergraduates, $68 \%$ - teachers. Table 1 shows the results of the survey.

TABLE 1 SURVEY RESULTS

\begin{tabular}{|l|l|l|l|l|l|l|l|l|l|l|l|}
\hline No. & Question content & \multicolumn{3}{|l|}{ Bachelor students } & \multicolumn{3}{l|}{ Master's students } & \multicolumn{2}{l|}{ Teachers } \\
\cline { 3 - 10 } & & yes & no & $\begin{array}{l}\text { do not } \\
\text { know }\end{array}$ & yes & no & $\begin{array}{l}\text { do not } \\
\text { know }\end{array}$ & yes & no & $\begin{array}{l}\text { do not } \\
\text { know }\end{array}$ \\
\hline 1. & $\begin{array}{l}\text { Do you know about the } \\
\text { PhD programme in } \\
\text { Kyrgyzstan? }\end{array}$ & $15 \%$ & $85 \%$ & - & $32 \%$ & $68 \%$ & - & $52 \%$ & $48 \%$ & - \\
\hline 2. & $\begin{array}{l}\text { Do you know about the } \\
\text { PhD programme abroad? }\end{array}$ & $36 \%$ & $64 \%$ & - & $41 \%$ & $49 \%$ & - & $68 \%$ & $32 \%$ & - \\
\hline 3. & $\begin{array}{l}\text { Do you think it is right to } \\
\text { leave the previous system } \\
\text { of training highly } \\
\text { qualified personnel } \\
\text { (candidates, doctors of } \\
\text { sciences)? }\end{array}$ & $12 \%$ & $69 \%$ & $19 \%$ & $10 \%$ & $74 \%$ & $16 \%$ & $56 \%$ & $37 \%$ & $7 \%$ \\
\hline 4. & $\begin{array}{l}\text { Do you think it is } \\
\text { necessary to completely } \\
\text { switch to PhD } \\
\text { programmes? }\end{array}$ & $59 \%$ & $14 \%$ & $27 \%$ & $68 \%$ & $12 \%$ & $20 \%$ & $14 \%$ & $30 \%$ & $56 \%$ \\
\hline
\end{tabular}




\begin{tabular}{|l|l|l|l|l|l|l|l|l|l|l|}
\hline 5. & $\begin{array}{l}\text { Do you think that the } \\
\text { training of highly } \\
\text { qualified personnel } \\
\text { (candidate, doctor of } \\
\text { science) should be } \\
\text { provided along with the } \\
\text { PhD? }\end{array}$ & $29 \%$ & $16 \%$ & $55 \%$ & $21 \%$ & $18 \%$ & $61 \%$ & $55 \%$ & $26 \%$ & $19 \%$ \\
\hline 6. & $\begin{array}{l}\text { Would you like to get an } \\
\text { education in the PhD } \\
\text { programme in } \\
\text { pedagogical areas? }\end{array}$ & $40 \%$ & $39 \%$ & $41 \%$ & $26 \%$ & $16 \%$ & $58 \%$ & $28 \%$ & $36 \%$ & $26 \%$ \\
\hline 7. & $\begin{array}{l}\text { Do you assess the } \\
\text { capabilities of Kyrgyz } \\
\text { Universities to prepare a } \\
\text { Doctor of Philosophy } \\
\text { (PhD) at a sufficient } \\
\text { level? }\end{array}$ & $69 \%$ & $17 \%$ & $14 \%$ & $66 \%$ & $22 \%$ & $12 \%$ & $68 \%$ & $11 \%$ & $21 \%$ \\
\hline
\end{tabular}

Thus, the study of the problem of attitude to the preparation of a $\mathrm{PhD}$ in pedagogical areas suggests that among students, master's, and teachers, the attitude remains quite skeptical. If teachers are concerned about organisational and legal uncertainty, the majority of master's students said that they are not familiar with the conditions, requirements for admission to doctoral studies, and the future prospects of this type of education. As for bachelor students, most of them, namely half of the respondents, are optimistic and intend to continue their pedagogical education in the future. At the same time, almost $50 \%$ of bachelor students are in no hurry to continue their professional education, citing the need to work and improve their financial condition, and they also expressed the opinion that there is not enough information about the $\mathrm{PhD}$ programme and its prospects.

Educational $\mathrm{PhD}$ training programmes in universities of the Kyrgyz Republic have not yet been implemented. The main reason for this is that many issues related to the study of the scientific-theoretical foundations and methodological differences in the preparation of a Doctor of Philosophy (PhD) and doctors in the field remain understudied, the lack of development of ways to synchronise existing educational programmes in the universities of the Kyrgyz Republic, as well as the lack of a regulatory framework for the implementation of doctoral programmes. But in the past year, the Government of the Kyrgyz Republic approved acts regulating the training of a Doctor of Philosophy $(\mathrm{PhD}) /$ doctors in the field. The corresponding order was signed on December 11, 2020 by the Acting Prime Minister A. Novikov, where the following was approved:

- Regulations on the organisation of postgraduate professional education (basic doctoral studies $(\mathrm{PhD}) /$ in the field) and the award of the Doctor of Philosophy $(\mathrm{PhD}) /$ doctor in the field;

- Minimum requirements for accredited educational programmes for the preparation of a Doctor of Philosophy $(\mathrm{PhD}) /$ doctors in the field, while maintaining the conventional academic degrees of candidate and doctor of science, etc. legislative acts related to the transition to the training of Doctors of Philosophy in the Kyrgyz Republic.

It follows from the above that in order to achieve effective implementation of the $\mathrm{PhD}$ programme in pedagogical areas in the Kyrgyz Republic, it is necessary to study in detail the organisational and legal, scientific, and methodological conditions and requirements for the implementation of this academic level of education, which will allow revealing the socio-pedagogical significance of this educational programme. 


\section{CONCLUSIONS}

The need to integrate the higher education system into the global educational space actualises the interest in the problem of $\mathrm{PhD}$ training and the implementation of programmes for awarding the academic degree of $\mathrm{PhD}$. Moreover, the current legislation of the Kyrgyz Republic has set a course for the implementation of $\mathrm{PhD}$ programmes in various scientific areas, based on which the third level of training Doctor of Philosophy $(\mathrm{PhD})$ /doctors in the field will begin in the universities of the Kyrgyz Republic from the 2021-2022 academic year. However, to achieve this goal, it is necessary to synchronise this type of education with the conventional form of training of scientific personnel. To do this, it is necessary that the problems of implementing this programme are studied taking into account the experience in neighboring countries, since we are in a similar educational space and have common historical and cultural traditions.

A purposeful study of the existing experience, as well as the scientific and theoretical foundations of the preparation of Doctors of Philosophy (PhD) and the award of an academic degree abroad and in the post-Soviet educational space, suggests that this form of training of scientific and pedagogical personnel has its advantages and problems that should be taken into account when developing and implementing this level of education. The Western model of education is significantly different from the educational programmes of the near abroad, the doctoral programme in the European scientific space involves mainly research, while training is quite independent and flexible. Therefore, it is necessary to create a domestic analogue of the $\mathrm{PhD}$ training in the field of "Pedagogy", while preserving, as much as possible, the existing experience of training scientific and pedagogical personnel, which meets the requirements of synchronisation of educational programmes. The most important element of such programmes should be the careful selection of future $\mathrm{PhD}$ students. To implement $\mathrm{PhD}$ programmes, not only the appropriate material and technical, methodological, and information base are required, but also specially developed scientific and methodological support.

Thus, the modernisation of professional higher education as an integral condition for the country's transition to multi-level education involves a number of steps aimed at changing the purpose, objectives, structure, and content of higher education, taking into account the principles of advanced education. And first of all, this applies to the $\mathrm{PhD}$ training in pedagogical fields, which should act as a mandatory component of specialised training and a necessary condition for general professional competence and should be recognised and accepted by the scientific and pedagogical community.

\section{REFERENCES}

Abdyrakhmanov, T.A. (2013). Transition Processes and Features of Democratic Transit in Kyrgyzstan. Bishkek: Kyrgyz State University.

Adamkulova, Ch.U. (2017). The introduction of a multilevel system of higher professional education in the Kyrgyz Republic. Azimuth of Scientific Research: Economics and Management, 6(4.21), 2123.

Asipova, N.A. (2015). Problems of modernization of the content of professional training of future university teachers in the context of a multilevel education system. News of the Kyrgyz Academy of Education, 3(35), 45-48.

Asipova, N.A. (2019). Organizational and methodological prerequisites for the training of $\mathrm{PhD}$ in the direction of "Pedagogy" in the Kyrgyz Republic. In Improving the training of scientific and pedagogical personnel in the transition to multilevel education: Materials of the International Scientific and Practical Conference (pp. 3-7). Retrieved from https://www.elibrary.ru/item.asp?id=42853994

Beregovaya, O.A., \& Kudashov, V.I. (2019). Internationalization of higher education in the context of globalization. Prospects for Science and Education, 3(39), 31-43.

Boldzhurova, I.S. (2006). The history of the development of the education system of the Kyrgyz Republic during the transition period: 1990-2005. Retrieved from 
https://www.dissercat.com/content/istoriya-razvitiya-sistemy-obrazovaniya-kyrgyzskoirespubliki-v-perekhodnyi-period-1990-2005

Cabinet of Ministers of the Kyrgyz Republic. (2020, September). Resolution of the Government of the Kyrgyz Republic No. 491 "On approval of the National Qualifications Framework”. Retrieved from https://www.gov.kg/ru/npa/s/2709

Chakraverty, D., Jeffe, D.B., Dabney, K.P., \& Tai, R.H. (2020). Exploring reasons that U.S. MD-PHD students enter and leave their dual-degree programs. International Journal of Doctoral Studies, $15,461-483$.

Danilchenko, V.M. (2004). Globalization and education in the XXI century. Higher Education Today, 3, 44-57.

Dobaev, K.D. (2017). On the problems of pedagogical education in Kyrgyzstan. In Organization of educational and educational work at the university. Retrieved from http://nbisu.moy.su/_1d/33/3358_ISUSUPATAEVA201.pdf

Dobaev, K.D., \& Mavlyanov, A.S. (2018). Science in Kyrgyzstan: Main trends and development problems. Izvestiya KAO, 1(37), 27-36.

Dos Santos Rocha, A., Combescure, C., \& Negro, F. (2020). The MD-PhD program in Geneva: A 10-year analysis of graduate demographics and outcomes. BMC Medical Education, 20(1), article number 425.

Dzhurinskiy, A.N. (2014). Comparative education. Challenges of the XXI century. Moscow: Prometey.

Goodyear-Smith, F., Stokes, T., McKinlay, E., Nixon, G., Lack, L., Fortier, R., \& Pullon, S. (2020). New Zealand general practice registrars' views on their academic learning needs during vocational training: Online survey. Education for Primary Care, 31(3), 136-144.

Grigoriev, A.N., \& Korshunov, G.V. (2016). Internationalization of education as a direction of the university's activity. Higher Education in Russia, 6(202), 135-141.

Kahwaji, A.T., Eddin, H.N., \& Palalić, R. (2020). Strategic leadership, strategic performance and core competencies in lebanon's education. Periodicals of Engineering and Natural Sciences, 8(4), $1968-1980$.

Karabalaeva, G.T., \& Asipova, N.A. (2020). Problems and prospects of training PHD doctors in the Kyrgyz Republic. Modern Problems of Science and Education, 2. Retrieved from http://www.science-education.ru/ru/article/view?id=29666

Karimova, B.S., \& Zhetpeisova, N.O. (2020). On innovative pedagogical technologies and training methods. International Journal of Learning and Change, 12(1), 15-24.

Koprov, V.M., \& Sapir, E.V. (2016). Integration processes in the innovative environment of higher education. Integration of Education, 20(3), 382-392. https://doi.org/10.15507/19919468.084.020.201603.382-392

Kozhobekov, M.Ch., Chekirov, K.B., \& Mambaeva, S.K. (2018). Features of the preparation of doctoral students (PHD) on the basis of the Kyrgyz-Turkish University Manas. International Journal of Experimental Education, 7, 18-23.

Kyrgyz National University Named After Jusup Balagsagyn. (2012, December). Order of the Ministry of Education and Science of the Kyrgyz Republic No 733/1 "On the organization of an experiment for the development and implementation of doctoral programs (PhD)'. Retrieved from https://www.knu.kg/ru/index.php?option=com_content\&view=article\&id=3581:-7331-121212-qphdq\& catid=910:2012-12-19-09-19-05\&Itemid=435

Meshcheryakov, D.A. (2007). Globalization of education and the common European educational space. Philosophy of Education, 1, 72-90.

Ministry of Justice of the Kyrgyz Republic. (2003, April). The Law of the Kyrgyz Republic No 92 "On Education”. Retrieved from http://cbd.minjust.gov.kg/act/view/ru-ru/1216

Ministry of Justice of the Kyrgyz Republic. (2011, August). Resolution of the Government of the Kyrgyz Republic No. 496 "On the establishment of a two-tier structure of higher professional education in the Kyrgyz Republic”. Retrieved from http://cbd.minjust.gov.kg/act/view/ru-ru/92802 
Nosik, V.V., Khomenko, M.M., \& Krasytska, L.V. (2021). Paradigm of reforming higher legal education in Ukraine in the context of training practising students. Journal of the National Academy of Legal Sciences of Ukraine, 28(2), 140-149.

Okolie, U.C., Igwe, P.A., Nwajiuba, C.A. Nwosu, H.E., \& Ogbaekirigwe, C.O. (2020). Does PhD qualification improve pedagogical competence? Journal of Applied Research in Higher Education, 12(5), 1233-1250. https://doi.org/10.1108/JARHE-02-2019-0049

Panibratsev, A.V. (2014). Globalization and problems of higher education in Russia. Scientific Bulletin of MSTU GA, 203, 49-55.

Pieterse, J.N. (1994). Globalization as Hybridization. International Sociology, 9(2), 49-51.

Pushkareva, E.A. (n.d.). Specificity of modern integration of education and science (socio-philosophical analysis). Retrieved from www.phil-ed.ru/Text/NamberJourn.html/disserts.ru/avioreferatidissertatsii-filosofiya/a287.php45

Rachmawati, I., Setyosari, P., Handarini, D.M., \& Hambali, I.M. (2021). Do social support and selfefficacy correlate with academic resilience among adolescence? International Journal of Learning and Change, 13(1), 49-62.

Rezaei, H. (2018). Internationalization or globalization of higher education. Journal of Education and Health Promotion, 7, article number 8. http://doi.org/10.4103/jehp.jehp_25_17

Sakimbaev, E.R. (2014). Training of doctor PhD in Kyrgyzstan, problems and solutions. Izvestia KAO, 4 , $59-63$.

Senashenko, V.S., \& Makarova, A.A. (2018). Educational hybrids in higher education in Russia. Higher Education in Russia, 27(8-9), 24-42. https://doi.org/10.31992/0869-3617-2018-27-8-9-24-42

Sitsinska, M., Sitsinskiy, A., Nikolaiev, V., Khadzhyradieva, S., \& Hasiuk, I. (2021). Legal and socioeconomic aspects of reforming Ukraine's higher education system. Journal of the National Academy of Legal Sciences of Ukraine, 28(1), 88-98.

Slepukhin, A. (2004). Higher school in the context of internationalization. Higher Education in Russia, 6 , $3-12$.

Tynalieva, B.K. (2019). Failed experiment: VAK about doctors of philosophy PhD. Retrieved from http://kutbilim.kg/2019/01/28/provalnyj-eksperiment-vak-o-doktorah-filosofii-phd 